\title{
BANK EFFICIENCY AND NON-PERFORMING LOANS: EVIDENCE FROM MALAYSIA AND SINGAPORE
}

\author{
Mohd Zaini Abd Karim, Sok-Gee Chan, Sallahudin Hassan*
}

\begin{abstract}
:
The objective of this paper is to investigate the relationship between non-performing loans and bank efficiency in Malaysia and Singapore. To achieve the objective, cost efficiency was estimated using the stochastic cost frontier approach assuming normal-gamma efficiency distribution model proposed by Greene (1990). The cost efficiency scores were then used in the second stage Tobit simultaneous equation regression to determine the effect of non-performing loans on bank efficiency. The results indicate that there is no significant difference in cost efficiency between banks in Singapore and Malaysia although banks in Singapore exhibit a higher average cost efficiency score. The Tobit simultaneous equation regression results clearly indicate that higher non-performing loan reduces cost efficiency. Likewise, lower cost efficiency increases non-performing loans. The result also support the hypothesis of bad management proposed by Berger and DeYoung (1992) that poor management in the banking institutions results in bad quality loans, and therefore, escalates the level of non-performing loans.
\end{abstract}

Keywords: bank efficiency, problem loans, stochastic cost frontier, tobit regression JEL Classification: G21

\section{Introduction}

The banking sector is still the primary form of financial intermediation in the Asian and Pacific region, and as such is the largest conduit for the mobilization of domestic savings, the main source of external capital to firms and the key player in the payment system. Consequently, the development of an efficient banking sector is crucial for the growth of the economies in the region. As liberalization of the banking sector around the world continues apace, banking markets in different countries are now becoming increasingly integrated. Moreover, foreign banks are allowed to set up branches in other countries, subject to the regulations of the home country. Furthermore, banking competition in the ASEAN region is expected to be more intense in the future with

* Mohd Zaini Abd Karim, College of Art and Sciences, Universiti Utara Malaysia (zaini500@uum. edu.my); Sok-Gee Chan, Institute of China Studies, University of Malaya (sokgee@yahoo.com); Sallahudin Hassan, College of Art and Sciences, Universiti Utara Malaysia (din636@uum.edu.my) 
the realization of ASEAN Free Trade Area (AFTA). ${ }^{1}$ In Malaysia and Singapore, both governments have been promoting consolidation of domestic banks to prepare them for the anticipated arrival of new foreign competition.

As foreign banks take a greater role in the market, the strength of the local banks will be put to the test. How these increased competitive pressures will affect banks depend in part on their ability to adapt and operate efficiently in the new environment. Banks that fail to do so will be driven out of the market by the more efficient ones. That is, the most efficient banks will have a competitive advantage. Therefore, information on banking efficiency when compared across nations is important, as this will enable policy makers to formulate appropriate and sound policies to direct their banking industry. Despite these facts, cross-country comparisons of banking efficiency in developing countries are lacking in the literature. ${ }^{2}$

At the same time, due to the Asian financial crisis, growth and innovation in both Malaysia and Singapore are constrained by banks whose capital has been eroded by the accumulation of non-performing loans (NPL). Although the non-performing loan ratios in Malaysia have fallen recently, the reduction in non-performing loan ratios were largely brought about by the transfer of NPLs from banks to public asset management companies. The question here is how non-performing loans affect the cost efficiency of banks. It is argued that it will have a detrimental effect since such banks will exert additional managerial effort and give additional expense dealing with these problem loans. These extra operating costs include, but are not limited to, a) additional monitoring of the delinquent borrowers and the value of their collateral, b) the expense of analyzing and negotiating possible workout arrangements, c) the cost of seizing, maintaining, and eventually disposing of collateral if default later occurs, and d) the diversion of senior management attention away from solving other operational problems. Faced with an exogenous increase in non-performing loans, even the most cost-efficient banks have to purchase the additional inputs necessary to administer these problem credits. By estimating the relationship between non-performing loans and bank efficiency, we can determine whether an increase in problem loans have a negative impact on bank efficiency.

The rest of the paper is organized as follows. Section 2 reviews the literature. Section 3 provides an overview of problem loans in Malaysia and Singapore. The hypothesized relationship between non-performing loans and cost efficiency is discussed in Section 4. Section 5 discusses the methodology and the data used. Section 6 presents the empirical results. Finally, Section 7 concludes.

1 ASEAN member countries are working towards the elimination of import duties on all products to achieve the eventual objective of a free trade area. The AFTA Council agreed that the target dates to achieve these objectives will be the year 2015 for the six original member countries (Brunei, Indonesia, Malaysia, the Philippines, Singapore, and Thailand) and the year 2018 for the new members of ASEAN.

2 To our knowledge, the only study on cross-country comparisons of banking efficiency in developing countries is Karim (2001). However; there are quite a number of bank efficiency studies on individual developing countries. Among others Bhattacharya, Lovell, and Sahay (1997) on India's commercial banks, Chaffai (1997) on Tunisia's banking industry, and Oral and Yolalan (1990) on the Turkish banking industry. 


\section{Review of Literature}

Issues of non-performing loans and cost efficiency are related in several important ways. First, a number of researchers have found that failing banks tend to be located far from the best practice frontier ${ }^{3}$ (e.g. Berger and Humphrey, 1992; Wheelock and Wilson, 1994). Thus, in addition to having high ratios of problem loans, banks approaching failure also tend to have lower cost efficiency. A number of other studies have found negative relationships between efficiency and problem loans even among banks that do not fail (Kwan and Eisenbeis, 1995). A positive relationship between asset quality and cost efficiency (DeYoung, 1997) suggests that the negative relationship between problem loans and cost efficiency holds for the population of banks as well as for the subset of failing banks.

Tsai and Huang (1999), by utilizing a translog cost function, examined the relationship between management quality and cost efficiency within Taiwan's banking industry. They discovered that asset quality and cost efficiency are related; the non-value-added activities of bad assets incur a negative consequence on the operating performance.

In recent years, studies on bank efficiency have taken into account asset quality, specifically non-performing loans. The omission of such a variable might lead to an erroneous bank efficiency measure (Mester, 1996). This is particularly true since a large proportion of non-performing loans may signal that banks use fewer resources than usual in their credit evaluation and loans monitoring process. In addition, non-performing loans lead to inefficiency in the banking sector as found by Altunbas et al. (2000), Fan and Shaffer (2004) and Girardone et al. (2004). This is because efficient banks are better at managing their credit risk as highlighted by Berger and DeYoung (1997).

By taking into account risk and quality factors into the estimation of banks' cost efficiency in the Japanese commercial banks for the period 1993 to 1996, Altunbas et al. (2000) finds that the level of non-performing loans are positively related to bank inefficiency. Furthermore, banks tend to experience a decrease in their scale efficiency level after controlling for risk factors. This result is also consistent with the study of bank efficiency levels in the U.S. by Hughes and Mester (1993) and on the evaluation of cost efficiency in the Italian banks by Girardone et al. (2004).

On the other hand, Fan and Shaffer (2004) analyzed profit efficiency of large commercial banks in the U.S. by accounting for non-performing loans. They find that, although non-performing loans are negatively related to banks' profit efficiency, it is not statistically significant.

\section{Overview of Problem Loans in Malaysia and Singapore}

Non-performing loans have been a hindrance to economic stability and growth of economies. In Malaysia and Singapore, non-performing loans continued to improve,

3 Berger and Humphrey (1992) defined that the best practice frontier is where the firms are considered to be fully efficient or achieve $100 \%$ efficiency level. The best practice frontier unit is achieved when there is no other decision making unit that can alter the combination of its inputs for a given output levels or vice versa. 
underpinned by higher reclassification of non-performing loans to performing status and recoveries, as well as efforts to achieve healthier balance sheets via loan write-offs. ${ }^{4}$ As a result, net non-performing loan ratios in the Malaysian banking system, since the Asian financial crisis, has gradually been in decline from a high of 13.6\% (3-month classification) in December 1998 to 3.2\% in 2007 (Table 1).

Table 1

Three-month Non-performing Loans in the Malaysian Banking System

\begin{tabular}{|l|c|c|}
\hline Year & $\begin{array}{c}\text { Gross non-performing } \\
\text { loans (RM'billion) }\end{array}$ & $\begin{array}{c}\text { As a percentage of } \\
\text { total advances }\end{array}$ \\
\hline $\mathbf{1 9 9 8}$ & 76,953 & 13.6 \\
\hline $\mathbf{1 9 9 9}$ & 65,540 & 11.0 \\
\hline $\mathbf{2 0 0 0}$ & 64,256 & 9.7 \\
\hline $\mathbf{2 0 0 1}$ & 76,976 & 11.5 \\
\hline $\mathbf{2 0 0 2}$ & 71,693 & 10.2 \\
\hline $\mathbf{2 0 0 3}$ & 65,774 & 8.9 \\
\hline $\mathbf{2 0 0 4}$ & 60,380 & 7.5 \\
\hline $\mathbf{2 0 0 5}$ & 53,570 & 5.8 \\
\hline $\mathbf{2 0 0 6}$ & 50,391 & 4.8 \\
\hline $\mathbf{2 0 0 7}$ & 41,763 & 3.2 \\
\hline
\end{tabular}

Source: Bank Negara Malaysia (BNM) monthly statistical bulletin.

The bulk of the banking system's non-performing loans is in the business sector ( $56 \%$ of total non-performing loans) followed by the household sector (41\%). In terms of banking system loans, the household sector accounts for the majority of total loans at $55 \%$, while the business sector accounts for $40 \%$. In Singapore, non-performing loans peaked for most banks in 1999 following the 1997 Asian financial crisis. The non-performing loan ratio for all banks (including multi-nationals with branches in Singapore) was $4.3 \%$ in 2005, down from $8.3 \%$ in 2001 (Monetary Authority of Singapore, 2006). This figure is much lower than in Malaysia.

Table 2 presents the loan disbursement and non-performing loans by sector in Malaysia. The ratio of non-performing loans to the total loans disbursed by sector clearly indicate that the education and health sector exhibit the highest ratio among other sectors with reported ratios of $16.83 \%$ in year 2006 and $14.20 \%$ in year 2007 . This is followed by finance, insurance and business activities with $12.02 \%$ in year 2006 and $7.26 \%$ in year 2006 . These sectors are mostly dominated by individual households borrowing for educational, health, and investment purposes. This is consistent with the BNM report; a large part of the non-performing loans comes from the household sector.

4 To resolve the non-performing loans problem in the banking sector, the Malaysian government established Danaharta, an asset management company, in 1998 to purchase non-performing loans from banking institutions. As of 31 March 2001, Danaharta had acquired loans amounting to around RM 48 billion from the financial system. 
Table 2

Loans Disbursed and Non-performing Loans by Sector in Malaysia

\begin{tabular}{|c|c|c|c|c|c|c|}
\hline \multirow[t]{2}{*}{ Sector } & \multicolumn{2}{|c|}{$\begin{array}{l}\text { Loans disbursed }{ }^{1} \\
\text { (in RM million) }\end{array}$} & \multicolumn{2}{|c|}{$\begin{array}{l}\text { Non-performing loans }{ }^{2} \\
\text { (in RM million) }\end{array}$} & \multicolumn{2}{|c|}{$\begin{array}{c}\text { Ratio of } \\
\text { non-performing loans } \\
\text { to loans disbursed }\end{array}$} \\
\hline & 2006 & 2007 & 2006 & 2007 & 2006 & 2007 \\
\hline Primary Agriculture & 13080.70 & 13593.30 & 516.50 & 462.30 & 3.95 & 3.40 \\
\hline Mining and Quarrying & 1327.30 & 1559.80 & 55.40 & 41.00 & 4.17 & 2.63 \\
\hline Manufacturing & 65239.30 & 73743.30 & 6181.30 & 5992.90 & 9.47 & 8.13 \\
\hline $\begin{array}{l}\text { Wholesale and Retail } \\
\text { Trade }\end{array}$ & 52144.50 & 55890.70 & 3961.60 & 3528.40 & 7.60 & 6.31 \\
\hline $\begin{array}{l}\text { Transport, Storage and } \\
\text { Communication }\end{array}$ & 11128.80 & 14367.80 & 526.90 & 428.40 & 4.73 & 2.98 \\
\hline $\begin{array}{l}\text { Finance, Insurance and } \\
\text { Business Activities }\end{array}$ & 33142.80 & 38752.90 & 3984.30 & 2815.10 & 12.02 & 7.26 \\
\hline Education and Health & 5923.00 & 6707.50 & 996.80 & 952.80 & 16.83 & 14.20 \\
\hline Household Sector & 332264.50 & 357381.70 & 23596.80 & 19041.90 & 7.10 & 5.33 \\
\hline Construction & 29654.30 & 30911.90 & 3104.10 & 2089.80 & 10.47 & 6.76 \\
\hline
\end{tabular}

${ }^{1}$ Loans disbursed by the banking system including Islamic banks.

${ }^{2}$ Loans that were in default for three months. Malaysia had, until the end of December 1997, defined non-performing loans as those loans up to six months overdue, and then revised the criterion to those loans up to three months overdue on January 1, 1998.

Source: BNM monthly statistical bulletin.

\section{Theoretical Relationship between Non-performing Loans and Bank Efficiency}

From the point of view of management accounting, bank asset quality and operating performance are positively related. If a bank's asset quality is inadequate (e.g. the loan amount becomes the amount to be collected), the bank will have to increase its bad debt losses as well as spend more resources on the collection of non-performing loans. This increase in non-performing loans in the banking industry can be due to external events, such as adverse situation in economic activities (Berger and DeYoung, 1997, refers to it as bad luck hypothesis). When banks list the loan amount for collection, banks will incur extra operating costs from non-value-added activities to handle and supervise the collection process. These non-value-added activities consist of constantly tracking the debtor's financial status, being cautious of the collateral value, discussing the amortization plan, paying expenses for contract negotiation, calculating the costs to withhold, deposit and dispose of collateral at the time the loans become non-payable. The costs include winning the trust from management and the public, preserving the banks from being rated poor as a consequence of external affairs, declining deposits because of a loss in credibility, and extra costs to monitor loan quality. Furthermore, higher future costs are generated by the ignorance of the problems from other operations when the loan quality issues grab the attention of the senior management. This escalation in cost, in turn, deteriorates bank efficiency. 
On the other hand, Berger and DeYoung (1997) also suggest that efficiency of the banking firms might affect the non-performing loans in the banking industry. The bad management hypothesis was developed to explain this relationship. Berger and DeYoung (1997) argue that bad management of the banking firms will result in banks inefficiency and affects the process of granting loans. The banks' management might not thoroughly evaluate their customers' credit application due to their poor evaluation skills. In addition, the problem of asymmetric information between lenders and borrowers further complicates the matter. Besides that, the management might not be efficient in managing loan portfolios. Consequently, this leads to lower credit ratings for the approved loans and high probability of default resulting in higher non-performing loans. Therefore, banks' inefficiencies might lead to higher non-performing loans.

\section{Methodology and Data}

To compare the cost efficiency of banks in Malaysia and Singapore, a cost efficiency score index is calculated by estimating a stochastic cost frontier function. We then regressed these scores against non-performing loans and other control variables to determine the relationship between non-performing loans and bank efficiency.

\section{Estimation of Cost Efficiency}

We used a cost function to measure efficiency instead of the production function because we want to determine how cost efficient a bank is as a financial intermediary in channeling funds from depositors to borrowers.

The SFA model proposed by Aigner et al. (1977), Meeusen and van de Broeck (1977), and Battese and Corra (1977) is used. The SFA cost function consists of variable costs, such as prices of the variable inputs, quantities of variable outputs and any fixed inputs or outputs needed for the production of goods and services in the banks as well as environmental factors that influence the costs of the banks and the random error (Berger et al., 1997). The general cost function is given by Equation 1 .

$$
y_{i t}=\alpha+X_{i t}^{\prime} \beta+Z_{i t}^{\prime} \gamma+\varepsilon_{i t} \text { where } \varepsilon_{i t}=v_{i t}+\mu_{i t}
$$

where $y_{i t}$ is total cost in logarithm form of bank $i$ at time $t, X_{i t}^{\prime}$ is the matrix of outputs and input prices in logarithm form, $Z_{i t}^{\prime}$ is defined as bank-specific or environmental variables for bank $i$ at time $t$. Next, the random error is defined as $\varepsilon_{i t}=v_{i t}+\mu_{i t}$ where $\mu_{i t}$ is the unconditional mean given $\varepsilon_{i t}$ and takes the value between 0 and 1 .

The translog cost function is then obtained based on SFA. We assume that the translog cost function defines the input use for all banks in the sample. The translog function is the most frequently selected function to measure bank efficiency (Greene 1980). ${ }^{5}$ Although the use of the translog cost function reduces the degrees of freedom in econometric estimation, this function is usually selected because it is a flexible

5 The function was developed by Kmenta (1967) as a means of approximating the CES production function and was introduced formally in a series of papers by Berndt, Christensen, Jorgensen and Lau, including Berndt and Christensen (1973) and Christensen et al. (1973). The literature has produced something of a competition in the development of exotic functional form. However, the translog function has remained the most popular. 
functional form that places no a priori restrictions on substitution possibilities among the factors of production and hence allows both economies and diseconomies of scale at different output levels.

$$
\begin{aligned}
& \operatorname{In} C_{i t}= \beta_{0} \\
&+\sum_{j=1}^{n} \beta_{j} \ln y_{j i t}+\sum_{k=1}^{m} \beta_{k} \ln w_{k i t}+\frac{1}{2} \sum_{j}^{n} \sum_{l}^{m} \beta_{j l} \ln y_{j} y_{l} \\
&+\frac{1}{2} \sum_{k}^{m} \sum_{p}^{m} \beta_{k p} \ln w_{k i t} \ln w_{p i t}+\frac{1}{2} \sum_{j}^{n} \sum_{k}^{m} \beta_{j k} \ln y_{j i t} \ln w_{k i t}+\beta_{q} t+u_{i t}+v_{i t}
\end{aligned}
$$

In equation (2), $\ln C_{i t}$ is the natural logarithm of total cost (discussion of what constitutes a bank's inputs and outputs is in the next section); $\ln y_{i t}=$ the natural logarithm of the jth output $(\mathrm{j}=1,2, \ldots, \mathrm{n}) ; \ln w_{\text {kit }}$ is the natural logarithm of the kth input price $(\mathrm{k}=1,2, \ldots, \mathrm{m})$; $\mathrm{t}$ is the year of observation; and $\beta$ are the coefficients to be estimated. The $v_{i t} s$ are random variables associated with measurement errors in the input variable or the effect of unspecified explanatory variables in the model, and the $u_{i t} \mathrm{~s}$ are non-negative random variables, associated with inefficiency of inputs used, given the levels of outputs and the quasi-fixed inputs.

The cost efficiency of inputs used for the $i$-th bank in the $t$-th year of observation, given the values of the outputs and inputs, is defined as the ratio of the stochastic frontier input use to observed input use. The stochastic frontier input use is defined by the value of input use if the cost inefficiency effect, $u_{i t}$, is zero (i.e., the bank is fully efficient in the use of input). If a translog stochastic frontier cost function is used, the cost efficiency for firm $i$ at time $t$ is defined by equation (3),

$$
C E_{i t}=\frac{C_{i t}\left(y_{i t}, w_{i t} ; \beta\right) \exp \left(v_{i t}\right)}{C_{i t}\left(y_{i t}, w_{i t} ; \beta\right) \exp \left(v_{i t}+u_{i t}\right)}=\exp \left(-u_{i t}\right)
$$

where $\mathrm{CE}_{\mathrm{it}} \leq 1$. The reciprocal of this value, $\exp \left(u_{i t}\right)$, can be interpreted as a measure of the cost inefficiency of input usage.

The estimation of cost efficiency employs the normal-gamma model proposed by Greene (1990). This model is more practical since it corrects the problems in stochastic frontier analysis as a result of the one-sided disturbances in the half-normal distribution model. The half-normal distribution model proposed by Aigner, Lovell, and Schmidt (1977) suffers from great inflexibility, because it uses a single parameter distribution with the assumption that the density of the disturbances mostly concentrates near zero. Hence, any deviation in the dependent variable will be extremely damaging to the analysis. In addition, a single outlier or unexpected observation from the sample can result in over specification of the efficiency scores irrespective of sample size used.

Greene (1990) argued that this model has an added advantage, since it does not require the assumption that the firm-specific inefficiency measures be predominantly near zero. Furthermore, since the range of random variable $\varepsilon$ is no longer restricted, the distribution of inefficiency can take different shapes.

To determine the relationship between non-performing loans and bank efficiency we employ the Tobit model since the efficiency scores is bounded between zero and one. The Tobit model developed by Tobin (1958) is also known as truncated or censored 
regression models where expected errors are not equal zero. Hence, estimation with Ordinary Least Squares (OLS) would lead to bias, since OLS assumes a normal distribution of the error term. More formally, the standard Tobit model can be defined as follows:

$$
\begin{aligned}
& E F F_{i}^{*}=\beta{ }^{\prime} \boldsymbol{X}+\varepsilon_{i}, \varepsilon_{i} \sim N\left(0, \sigma^{2}\right) \text { if } 0<E F F_{i}^{*}<1 \\
& E F F_{i}=0 \text { if } E F F_{i}^{*}=0 \\
& E F F_{i}=1 \text { otherwise }
\end{aligned}
$$

where $E F F_{i}{ }^{*}$ is the cost efficiency scores from the stochastic cost frontier estimation, $\beta$ represents a vector of parameters to be estimated, $\boldsymbol{X}$ is a vector of explanatory variables, and $\varepsilon_{i}$ is a normally distributed error term. The explanatory variables for this study are NPL, STATE, FOREIGN, ASSET, and AGE.

$N P L$ is the ratio of non-performing loans to total loans. Variables to control for other factors that affect bank efficiency are as follows; STATE is a dummy variable that takes a value of 1 if the bank is state-owned and 0 if the bank is privately-owned; FOREIGN is the dummy variable that takes a value of 1 if the bank is foreign bank and 0 if it is local; ASSET is the natural logarithm of the value of total assets. It measures the size effect of firm; $A G E$ is the age of firm to control for bank experience. Banks that were established earlier are expected to be more efficient. However, after the bank reaches some age, the incremental effect of experience will be negligible.

It is believed that the relationship between non-performing loans and efficiency are bi-directional instead of unidirectional. Low efficiency reflects poor daily operations and loan portfolio management practices. Poor management skills in terms of credit scoring will lead to negative returns on a high proportion of loans and thus higher non-performing loans. Hence, efficiency also affects non-performing loans (Berger and DeYoung, 1997). Therefore, a Tobit simultaneous equation regression model (Equation 4 and 5) is used to estimate the relationship between non-performing loans and efficiency to control for the simultaneity effect.

$$
\begin{aligned}
& E F F_{i t}=\alpha_{0}+\delta_{1} N P L_{i t}+\alpha_{1} \text { STATE }_{i t}+\alpha_{2} \text { FOREIGN }_{i t}+\alpha_{3} \text { ASSET }_{i t}+\alpha_{4} A G E_{i t}+\varepsilon \\
& N P L_{i t}=\beta_{0}+\delta_{1} E F F_{i t}+\beta_{1} S T A T E_{i t}+\beta_{2} \text { FOREIGN }_{i t}+\beta_{3} A S S E T_{i t}+\beta_{4} A G E_{i t}+v
\end{aligned}
$$

\section{Choice of Banks' Input and Output}

In general, the literature on banking efficiency has considered two approaches in considering what constitute a bank's output and costs. ${ }^{6}$ For this study, the intermediation approach is employed for two reasons. First, we are concerned with how cost efficient the bank is as a financial intermediary in channeling funds from depositors to borrowers. Second, the number of accounts for each output category in the bank data is unavailable. Hence, our banks' total cost will include the sum of expenses on

6 Little agreement exists as to what a bank produces or how to measure output. In general, though, two approaches are used to examine the banking industry; the production and intermediation approach is discussed in Humphrey (1985). 
wages and salaries, land, buildings, and equipment and interest on deposits, while the outputs are dollar amounts of total loans, total deposits, and investments. All the output variables take the value of USD million. The input price will include expenses on wages and salaries per employee (unit price of labor), expenses on land, buildings, and equipment per dollar of assets (unit price of physical capital), and expenses on interest per dollar of deposits (unit price of financial capital). The price of labor is computed using the total personnel expenses to total assets, the price of physical capital takes the ratio of other operating expenses to total fixed asset, and the price of financial capital is computed by dividing the total interest expenses with total deposits.

\section{Data}

The data for estimating the cost frontier function for ASEAN will be drawn from IBCA BANKSCOPE and the Bank's Annual Report. Table 3 presents a summary statistics of all the banks in the sample. All dollar amounts are in USD million. They are in real 2000 terms and have been converted using individual country GDP deflators.

The average asset size of the banks in the whole sample (both local and foreign banks) over the period 1995 to 2000 is USD 6,665.44 million. The average asset size for local banks in Singapore is the biggest in our sample. Their average asset size is USD 14,534.03 million with a maximum asset size USD 31,521.94 million. The average asset size of Malaysia's local banks is USD 4,161.80 million with a maximum asset size of USD 29,608.89 million.

Table 3

\section{Summary Statistics for Sample Banks}

\begin{tabular}{|c|c|c|c|c|c|c|c|c|}
\hline & $\begin{array}{l}\text { Assets } \\
\text { (USD } \\
\text { million) }\end{array}$ & $\begin{array}{l}\text { Loans } \\
\text { (USD } \\
\text { million) }\end{array}$ & $\begin{array}{l}\text { Deposits } \\
\text { (USD } \\
\text { million) }\end{array}$ & $\begin{array}{l}\text { Invest- } \\
\text { ments } \\
\text { (USD } \\
\text { million) }\end{array}$ & $\begin{array}{c}\text { Non- } \\
\text { performing } \\
\text { Loans } \\
\text { (USD } \\
\text { million) }\end{array}$ & $\begin{array}{l}\text { Price of } \\
\text { Labor }\end{array}$ & $\begin{array}{l}\text { Price of } \\
\text { Capital }\end{array}$ & $\begin{array}{l}\text { Price of } \\
\text { Funds }\end{array}$ \\
\hline \multicolumn{9}{|c|}{ Malaysia } \\
\hline Mean & 4161.80 & 8059.72 & 10613.99 & 4422.02 & 764.73 & 90.39 & 35.83 & 540.66 \\
\hline $\begin{array}{l}\text { Standard } \\
\text { Deviation }\end{array}$ & 5331.31 & 10349.77 & 13271.11 & 6003.48 & 1093.33 & 114.39 & 50.45 & 712.75 \\
\hline Minimum & 39.64 & 146.30 & 311.40 & 100.30 & 1.10 & 4.00 & 0.72 & 14.20 \\
\hline Maximum & 29608.89 & 64509.60 & 76111.40 & 32419.70 & 6988.70 & 654.50 & 247.10 & 5656.60 \\
\hline \multicolumn{9}{|c|}{ Singapore } \\
\hline Mean & 14534.03 & 8490.23 & 12444.31 & 5592.94 & 636.42 & 65.31 & 61.75 & 500.81 \\
\hline $\begin{array}{l}\text { Standard } \\
\text { Deviation }\end{array}$ & 13222.08 & 10335.04 & 16435.36 & 8518.82 & 916.37 & 85.89 & 76.43 & 653.02 \\
\hline Minimum & 418.88 & 522.20 & 503.10 & 0.60 & 10.90 & 1.50 & 2.50 & 15.00 \\
\hline Maximum & 31521.94 & 27740.70 & 46718.10 & 26820.10 & 3035.10 & 239.30 & 218.80 & 1984.90 \\
\hline
\end{tabular}


Table 4

Maximum-Likelihood Estimates of the Translog Stochastic Frontier Cost Function

\begin{tabular}{|c|c|c|c|c|}
\hline & Coefficient & Standard Error & t-ratio & P-value \\
\hline Constant & 1.4389 & 2.0439 & 0.7040 & 0.4814 \\
\hline $\operatorname{Ln}\left(r_{1}\right)$ & -0.1181 & 0.4523 & -0.2610 & 0.7940 \\
\hline $\operatorname{Ln}\left(r_{2}\right)$ & 0.4330 & 0.2395 & $1.8080^{*}$ & 0.0706 \\
\hline $\operatorname{Ln}\left(r_{3}\right)$ & 2.3371 & 0.6769 & $3.4530^{* * *}$ & 0.0006 \\
\hline $\operatorname{Ln}\left(y_{1}\right)$ & -0.3578 & 0.7443 & -0.4810 & 0.6308 \\
\hline $\operatorname{Ln}\left(y_{2}\right)$ & 2.2266 & 1.7147 & 1.2990 & 0.1941 \\
\hline $\operatorname{Ln}\left(y_{3}\right)$ & -0.1705 & 2.3249 & -0.0730 & 0.9416 \\
\hline $\operatorname{Ln}\left(r_{1}\right)^{2}$ & 0.0397 & 0.0434 & 0.9160 & 0.3599 \\
\hline $\operatorname{Ln}\left(r_{2}\right)^{2}$ & 0.0109 & 0.0112 & 0.9770 & 0.3288 \\
\hline $\operatorname{Ln}\left(r_{3}\right)^{2}$ & 0.4141 & 0.1016 & $4.0780^{* * *}$ & 0.0000 \\
\hline $\operatorname{Ln}\left(y_{1}\right)^{2}$ & 0.0048 & 0.0276 & 0.1740 & 0.8618 \\
\hline $\operatorname{Ln}\left(y_{2}\right)^{2}$ & 0.1299 & 0.2461 & 0.5280 & 0.5974 \\
\hline $\operatorname{Ln}\left(y_{3}\right)^{2}$ & -0.6017 & 0.5809 & -1.0360 & 0.3004 \\
\hline $\operatorname{Ln}\left(r_{1}\right) \operatorname{Ln}\left(r_{2}\right)$ & 0.1565 & 0.0396 & $3.9490^{* * *}$ & 0.0001 \\
\hline $\operatorname{Ln}\left(r_{1}\right) \operatorname{Ln}\left(r_{3}\right)$ & -0.1816 & 0.0809 & $-2.2450^{* *}$ & 0.0248 \\
\hline $\operatorname{Ln}\left(r_{2}\right) \operatorname{Ln}\left(r_{3}\right)$ & -0.1085 & 0.0558 & $-1.9440^{*}$ & 0.0519 \\
\hline $\operatorname{Ln}\left(y_{1}\right) \operatorname{Ln}\left(y_{2}\right)$ & -0.3842 & 0.3187 & -1.2050 & 0.2280 \\
\hline $\operatorname{Ln}\left(y_{1}\right) \operatorname{Ln}\left(y_{3}\right)$ & 0.4836 & 0.3361 & 1.4390 & 0.1502 \\
\hline $\operatorname{Ln}\left(y_{2}\right) \operatorname{Ln}\left(y_{3}\right)$ & 0.3574 & 0.8121 & 0.4400 & 0.6598 \\
\hline $\operatorname{Ln}\left(r_{1}\right) \operatorname{Ln}\left(y_{1}\right)$ & 0.1477 & 0.1159 & 1.2740 & 0.2027 \\
\hline $\operatorname{Ln}\left(r_{1}\right) \operatorname{Ln}\left(y_{2}\right)$ & 0.2077 & 0.3284 & 0.6320 & 0.5271 \\
\hline $\operatorname{Ln}\left(r_{1}\right) \operatorname{Ln}\left(y_{3}\right)$ & -0.2577 & 0.4073 & -0.6330 & 0.5268 \\
\hline $\operatorname{Ln}\left(r_{2}\right) \operatorname{Ln}\left(y_{1}\right)$ & -0.0526 & 0.0411 & -1.2810 & 0.2002 \\
\hline $\operatorname{Ln}\left(r_{2}\right) \operatorname{Ln}\left(y_{2}\right)$ & -0.1680 & 0.1325 & -1.2680 & 0.2048 \\
\hline $\operatorname{Ln}\left(r_{2}\right) \operatorname{Ln}\left(y_{3}\right)$ & 0.2106 & 0.1496 & 1.4070 & 0.1593 \\
\hline $\operatorname{Ln}\left(r_{3}\right) \operatorname{Ln}\left(y_{1}\right)$ & -0.1829 & 0.1819 & -1.0050 & 0.3147 \\
\hline $\operatorname{Ln}\left(r_{3}\right) \operatorname{Ln}\left(y_{2}\right)$ & 0.7707 & 0.2984 & $2.5830^{* * *}$ & 0.0098 \\
\hline $\operatorname{Ln}\left(r_{3}\right) \operatorname{Ln}\left(y_{3}\right)$ & -0.6101 & 0.4391 & -1.3890 & 0.1647 \\
\hline \multicolumn{5}{|c|}{ Variance parameters for compound error } \\
\hline Theta & 5.2758 & 1.5108 & $3.4920^{* * *}$ & 0.0005 \\
\hline $\mathbf{P}$ & 0.5308 & 0.0743 & $7.1470^{* * *}$ & 0.0000 \\
\hline Sigmav & 0.1535 & 0.0188 & $8.1470^{* * *}$ & 0.0000 \\
\hline \multicolumn{2}{|c|}{ Log likelihood function } & \multicolumn{2}{|l|}{39.7503} & \\
\hline \multicolumn{5}{|c|}{ Variances: } \\
\hline \multicolumn{2}{|c|}{$\begin{array}{l}\text { Sigma-squared (v) } \\
\text { Sigma-squared (u) } \\
\text { Sigma (v) } \\
\text { Sigma (u) }\end{array}$} & $\begin{array}{l}0.0220 \\
0.0196 \\
0.1485 \\
0.1399\end{array}$ & & \\
\hline
\end{tabular}

Notes: "significant at $10 \%$ level, " significant at $5 \%$ level.

** significant at $1 \%$ level. 
The price of labor and price of funds in Malaysia is relatively higher as compared to Singapore. Besides that, Singapore banks seems to be relatively superior in their output production, since the total loans and deposits generated from the traditional banking activities are relatively higher compared to the commercial banks in Malaysia. In addition, the amounts of non-performing loans of the commercial banks in Singapore are relatively lower compared to Malaysia, with the reported non-performing loans of USD 636.42 million whereas in Malaysia the reported figure of non-performing loans is USD 764.73.

\section{Results and Discussion}

This section reports the results obtained from estimating the stochastic cost frontier, including parameter estimates and hypothesis testing. Following Karim (2001), ordinary least squares (OLS) was first used to check whether OLS assumptions were not violated. The Box-Pierce statistics were insignificant indicating that the error terms were non-autocorrelated, while the Breusch-Pagan statistics were also insignificant indicating that the null hypothesis of homoskedasticity cannot be rejected. We then proceed to estimate the stochastic cost frontier using the maximum likelihood method. The maximum-likelihood estimates for the twenty-seven parameters in the translog stochastic cost frontier for input use (defined by Equation 1) are presented in Table 4. The inputs employed in this model are the price of labor $\left(\mathrm{r}_{1}\right)$, price of capital $\left(\mathrm{r}_{2}\right)$, and the price of funds $\left(\mathrm{r}_{3}\right)$, while the outputs used in this study are total investment $\left(\mathrm{y}_{1}\right)$, total loans $\left(\mathrm{y}_{2}\right)$, and total deposits $\left(\mathrm{y}_{3}\right)$.

From the estimation obtained based on standard translog specification, it is found that the cost of the banks in the sample study are positively related to the price of capital and the price of funds, and they are statistically significant at $10 \%$ and $1 \%$ significance level respectively. This is consistent with the theory in which an increase in the price of factors of production will lead to an increase in the cost of the commercial banks.

The descriptive statistics for the average efficiency scores obtained from the translog cost function for both local and foreign commercial banks in Singapore and Malaysia are presented Table 5.

Table 5

Descriptive Statistics on Average Cost Efficiency Scores for the Commercial Banks in Singapore and Malaysia from Year 1995 to 2000

\begin{tabular}{|l|c|c|c|c|}
\hline & Mean & Standard Deviation & Minimum & Maximum \\
\hline Full Sample & 0.8768 & 0.0809 & 0.5236 & 0.9654 \\
\hline \multicolumn{5}{|c|}{ Singapore } \\
\hline Full & 0.9253 & 0.0275 & 0.8574 & 0.9654 \\
\hline Local & 0.9277 & 0.0227 & 0.8785 & 0.9611 \\
\hline Foreign & 0.9225 & 0.0329 & 0.9654 \\
\hline \multicolumn{5}{|c|}{ Malaysia } \\
\hline Full & 0.8688 & 0.0840 & 0.8574 & 0.9612 \\
\hline Local & 0.8809 & 0.0677 & 0.5236 & 0.9612 \\
\hline Foreign & 0.8492 & 0.1028 & 0.5418 & 0.9561 \\
\hline
\end{tabular}


The average cost efficiency score of the full sample is $87.68 \%$ which means that the banks are wasting $12.32 \%$ of their inputs mix. Hence, banks may further reduce their input mix by $12.32 \%$ in order to enhance their efficiency level. From Table 5, it is clearly indicated that the commercial banks in Singapore are relatively cost efficient as compared to the commercial banks in Malaysia for both local and foreign commercial banks. This may be due to the reason that Singapore, as a whole, is the most economically efficient country in the region. Apart from that, a relatively more efficient commercial banking industry in Singapore might also due to the openness of the country in terms of foreign entrance to its banking sector as compared to Malaysia. As highlighted by Karim (2001), tighter regulatory framework in one country may also affect the efficiency level of the commercial banks, and this is consistent with the results obtained in this study. However, the difference in both mean and variance efficiency score are not statistically significant (Table 6).

Table 6

Test for Variance and Mean Difference

\begin{tabular}{|l|c|c|}
\hline & Singapore & Malaysia \\
\hline Mean cost efficiency & 0.8768 & 0.8688 \\
\hline Variance cost efficiency & 0.0066 & 0.0071 \\
\hline \multicolumn{2}{|l|}{} \\
\hline F test: Two-sample for Variance & 0.9278 & \\
\hline F-statistic & 0.3054 & \\
\hline P(F<=f) one-tail & \\
\hline \multicolumn{2}{|l|}{} \\
\hline t-test: Two-Sample Assuming Equal Variances \\
\hline t-statistic & 0.9283 & \\
\hline$P(T<=t)$ two-tail & 0.3539 & \\
\hline
\end{tabular}

Notes: "significant at 10\% level, "* significant at 5\% level, "** significant at $1 \%$ level.

Hence, there is no sufficient evidence to conclude that there are differences in the cost efficiency level between commercial banks in Singapore and Malaysia even though the commercial banks in Singapore exhibit a higher average cost efficiency score than the commercial banks in Malaysia.

To study the effect of non-performing loans on the commercial banks' performance and vice-versa, a Tobit simultaneous equation regression model (Equation 4 and 5) is used to estimate the relationship between non-performing loans and efficiency to control for the simultaneity effect. The Tobit regression model was used in this study as the cost efficiency scores take on values between 0 and 1 . The estimation results are presented in Table 7. 
Table 7

Tobit Simultaneous Equation Model Estimates

\begin{tabular}{|c|c|c|c|}
\hline \multicolumn{4}{|c|}{ Dependent: EFF } \\
\hline & Coefficient & Standard Error & t-ratio \\
\hline Constant & 0.598 & 0.225 & $2.659^{* * *}$ \\
\hline NPL & -1.869 & 0.277 & $-6.741^{* * *}$ \\
\hline STATE & 0.032 & 0.056 & 0.568 \\
\hline FOREIGN & -0.026 & 0.066 & -0.400 \\
\hline ASSET & 0.057 & 0.034 & $1.665^{*}$ \\
\hline AGE & 0.000 & 0.001 & -0.009 \\
\hline \multicolumn{4}{|c|}{ Dependent: NPL } \\
\hline & Coefficient & Standard Error & t-ratio \\
\hline Constant & 0.320 & 0.149 & $2.144^{* *}$ \\
\hline EFF & -0.535 & 0.079 & $-6.741^{* * *}$ \\
\hline STATE & 0.017 & 0.031 & 0.559 \\
\hline FOREIGN & -0.014 & 0.035 & -0.403 \\
\hline ASSET & 0.030 & 0.016 & $1.874^{*}$ \\
\hline AGE & 0.000 & 0.000 & -0.009 \\
\hline \multicolumn{4}{|c|}{ Variance parameters } \\
\hline $\mathbf{s}_{12} / \mathbf{s}_{22}$ & 1.869 & 0.277 & $6.741^{* \star *}$ \\
\hline$s\left[e_{1}, e_{2}\right]$ & 0.000 & 0.000 & $9.008^{* * *}$ \\
\hline
\end{tabular}

Notes: " significant at $10 \%$ level, "* significant at $5 \%$ level, ${ }^{* * *}$ significant at $1 \%$ level.

The results obtained from the Tobit simultaneous equation model show that the coefficient of NPL in the equation where cost efficiency is the dependent variable is negative and is statistically significant at the $1 \%$ level. This indicates that non-performing loan have a negative effect on cost efficiency. The result is consistent with the studies by Altunbas et al. (2000), Fan and Shaffer (2004), and Girardone et al. (2004). As pointed out by Berger and DeYoung (1997), the negative relationship exists since banks will incur extra operating costs from non-value-added activities, such as handling and supervising the collection process of the non-performing loans. The efficient banks are better at managing their credit risk and hence it leads to lower non-performing loans.

Likewise, the results show that the coefficient of EFF in the equation where NPL is the dependent variable is negative and statistically significant at the $1 \%$ level. The result indicates that an increase in bank efficiency decreases non-performing loans. This supports the bad management hypothesis proposed by Berger and DeYoung (1997) which suggests that poor management in banking institutions will result in bad quality loans. The results also found that the banks total assets, which are used to control for scale of operation, are positively related to cost efficiency. This shows that banks enjoy economies of scale, which is consistent with theory. 


\section{Conclusion}

The objectives of this paper are twofold. First, the paper examines whether there are significant differences in banking efficiency between Malaysian and Singaporean banks. Second, the paper seeks to explain the relationship between non-performing loans and bank efficiency. Using actual data of both Malaysian and Singaporean banks from 1995 to 2000, we estimate bank's cost efficiency by the stochastic cost frontier method. The efficiency scores are then used in the second stage Tobit analysis to investigate the relationship between non-performing loans and banking efficiency.

The cost efficiency estimation results indicate an average cost efficiency score of $87.68 \%$ for the full sample. This suggests that banks are wasting $12.32 \%$ of their inputs. The results also indicate that there is no significant differences in the cost efficiency level between commercial banks in Singapore and Malaysia even though the commercial banks in Singapore exhibit a higher average cost efficiency score than the commercial banks in Malaysia. The Tobit regression results clearly indicate that higher non-performing loan reduces cost efficiency. Likewise, lower cost efficiency increases non-performing loans. The results are consistent with the studies by Altunbas et al. (2000), Fan and Shaffer (2004), and Girardone et al. (2004) that found that non-performing loans lead to inefficiency in the banking sector. In addition, the results also support the hypothesis of bad management proposed by Berger and DeYoung (1997), which suggests that poor management in the banking institutions results in bad quality loans, and therefore, escalates the level of non-performing loans.

\section{References}

Aigner, D., Lovell, C., Schmidt, P. (1977). "Formulation and Estimation of Stochastic Frontier Production Function Models." Journal of Econometrics, 6, pp. 21-37.

Allen, L., Rai, A. (1996), "Operational Efficiency in Banking: An international Comparison." Journal of Banking and Finance, Vol. 20, pp. 655-672.

Altunbas, Y., Liu, M. H., Molyneux, P., Seth, R. (2000). "Efficiency and Risk in Japanese Banking." Journal of Banking and Finance, Vol. 24, pp.1605-1628.

Bank Negara Malaysia (BNM), Monthly Statistical Bulletin, various issues.

Battese, G. E., Corra, G. S. (1977). "Estimation of a Production Frontier Model: With Application to the Pastoral Zone of Eastern Australia." Australian Journal of Agricultural Economics, Vol. 21, pp. 169-179.

Berger, A. N., DeYoung, R. (1997). "Problem Loans and Cost Efficiency in Commercial Banks." Journal of Banking and Finance, Vol. 21, pp. 849-870.

Berger, A. N., Humphrey, D. B. (1992), "Measurement and Efficiency Issues Commercial Banking," in Griliches, Z., ed., "Output Measurement in the Services Sectors." National Bureau of Economic Research Studies in Income and Wealth, pp. 245-279, Chicago: University of Chicago Press.

Berndt, E. R. and L. R. Christensen (1973), "The Translog Function and the Substitution of Equipment, Structures, and Labor in U.S. Manufacturing, 1929-1968." Journal of Econometrics, 1(1), pp. 81-113.

Bhattacharya, A., Lovell, C. A. K., Sahay, P. (1997), "The Impact of Liberalization on the Productive Efficiency of Indian Commercial Banks." European Journal of Operational Research, 98, pp. 332-345. 
Chaffai, M. (1997), "Estimating Input-Specific Technical Inefficiency: The Case of the Tunisian Banking Industry." European Journal of Operational Research, 98, pp. 314-331.

Christensen, L. R., Jorgensen, D. W., Lau, L. J. (1973), Transcendental Logarithmic Production Frontiers, The Review of Economics and Statistics, 55(1), pp. 28-45.

DeYoung, R. (1997), "X-Efficiency and Management Quality in National Banks." Journal of Financial Services Research, Vol. 15, No. 2.

Fan, L., Shaffer, S. (2004). "Efficiency versus Risk in Large Domestic US Banks." Managerial Finance, Vol. 30, pp. 1-19.

Farrell, M. J. (1957). "The Measurement of Productive Efficiency." Journal of the Royal Statistical Society. Series a (General), 120, pp. 253-290.

Girardone, C., Molyneux, P., Gardener, E. P. (2004). "Analysing the Determinants of Bank Efficiency: The Case of Italian Banks." Applied Economics, 36, pp. 215-227.

Greene, W. (1980), "Maximum Likelihood Estimation of Econometric Frontier Functions." Journal of Econometrics, 13, pp. 27-56.

Greene, W. H. (1990). "A Gamma-distributed Stochastic Frontier Model." Journal of Econometrics, 46, pp. 141-163.

Hughes, J. P., Mester, L. J. (1993). "A Quality and Risk-adjusted Cost Function for Banks: Evidence on the 'Too-Big-to-Fail' Doctrine." Journal of Productivity Analysis, 4, pp. 293-315.

Humphrey, D. B. (1985), "Costs and Scale Economies in Bank Intermediation," in Aspinwall, R. C., Eisenbeis, R., eds., Handbook of Banking Strategy. New York: Wiley, pp. 745-783.

Hymer, S. (1976). The International Operations of National Firms: a Study of Direct Foreign Investment. Cambridge, Massachusetts: MIT Press.

Karim, M. Z. A. (2001), "Comparative Bank Efficiency Across Select ASEAN Countries." ASEAN Economic Bulletin, 18 (3), pp. 289-304.

Kmenta, J. (1967), "On Estimation of the CES Production Function." International Economic Review, 8, pp. $180-189$.

Kwan, S., Eisenbeis, R. (1995) "An Analysis of Inefficiencies in Banking." Journal of Banking and Finance, 19(3-4), pp. 733-734.

Meeusen, W., van den Broeck, J. (1977), "Efficiency Estimation from Cobb-Douglas Production Functions with Composed Error." International Economic Review, 18, pp. 435-44.

Mester, L. J. (1996). "A Study of Bank Efficiency Taking into Account Risk-Preferences." Journal of Banking and Finance, Vol. 20, pp. 1025-1045.

Mian, A. (2006). "The Limits of Foreign Lending in Poor Countries." The Journal of Finance, Vol. 61, pp. 1465-1505.

Monetary Authority of Singapore (2006). Annual Report 2006. Singapore: MAS

Oral, M., Yolalan, R. (1990), "An Empirical Study on Measuring Operating Efficiency and Profitability of Bank Branches." European Journal of Operational Research, 46, pp. 282-294.

Tsai, D. H., Huang, F. W. (1999), "Management Quality and Bank Efficiency: Empirical Evidence for Taiwanese Banks." Management Review, 18 (3), pp. 35-55.

Wheelock, D. C., Wilson, P. W. (1995), "Explaining Bank Failures: Deposit Insurance, Regulation, and Efficiency." Review of Economics and Statistics, 77, pp. 689-700. 